DOI: $10.31866 / 2410-1915.20 .2019 .172394$

УДК 640.43"20":392.8(=161.2)

\title{
НАЦІОНАЛЬНІ ЕКОКУЛЬТУРНІ ТРАДИЦІЇ В СУЧАСНИХ РЕСТОРАННИХ ЗАКЛАДАХ
}

\author{
Братіцел Марина Леонідівна
}

\section{Асистент,}

ORCID: 0000-0001-9206-3479, frog2014137@gmail.com, Київський національний університет культури і мистецтв, вул. Є. Коновальия, 36, Київ, Україна, 01133

Мета статті - виявити специфіку вітчизняних екокультурних традицій харчування в сучасних ресторанах національної української кухні. Методологія дослідження заснована на сукупності фундаментальних принципів теорії соціальної екології, принципів соціально-екологічного та культурного підходу до вивчення екологічної культури. Враховуючи міждисциплінарний характер даного питання, у процесі дослідження та аналізу національних екокультурних традицій в сучасних ресторанних закладах застосовувались інтегровані, ціннісні, структурно-функціональні та факторні підходи; методи моделювання, системного аналізу та узагальнення, які сприяли розумінню механізмів реалізації основних принципів екологічної культури в галузі ресторанного господарства. Наукова новизна. Визначено особливості національних екокультурних традицій харчування в сучасних ресторанах української кухні та виявлено, що вони співпадають зі всесвітньо визнаними базовими принципами екологічної культури XXI ст. Висновки. Одним із трендів вітчизняних закладів ресторанного господарства на сучасному етапі $\epsilon$ підвищення престижності традиційних продуктів та страв української кухні, звернення до сформованих протягом століть національних екокультурних норм харчування. Це пояснюється світовою тенденцією - активізацією екологічної свідомості людини, осмисленням особистої відповідальності за збереження населення Землі, яке відбувається завдяки зміні світосприйняття, перегляду культурних цінностей, з метою формування та розвитку екологічної культури XXI ст. як необхідної передумови для еволюціонування цивілізації. Розвиток національної української кухні відіграє важливу роль не лише в процесі популяризації певних продуктів харчування, а й в процесі іх адаптування до вимог і потреб, що відповідають культурній нормі українців на сучасному етапі.

Ключові слова: українська кухня; екологічна культура; екокультурні традиції; харчування; заклади ресторанного господарства.

\section{Вступ}

Одну з базових екологічних функцій - збезпечення та регулювання процесів обміну енергією між організмом людини та навколишнім середовищем виконує їжа, яка водночас $є$ важливою та невід’ємною частиною національної культури, джерелом дослідження історії народу

(C) Братіцел М. Л., 2019 
та механізмів трансляції культурного спадку. Науковці одностайні в твердженні, що їжа перетворюється на виключно культурний феномен в процесі виробництва, приготування та вживання, оскільки людина обирає те, що їсть відповідно до економічних та екологічних факторів, харчових властивостей та смакових переваг (Montanari, 2013, p. 12).

Розвиток національної української кухні на сучасному етапі засвідчує величезний вплив традицій попередніх історичніх періодів, що актуалізує дослідження її специфіки в контексті екокультурної концепції (підтримки балансу з навколишнім середовищем) та з позиції традиційного використання регіональних ресурсів.

Сучасними культурологами національні особливості харчування досліджуються в різноманітних аспектах. Наприклад, I. де Гаріне «Соціокультурні аспекти харчування» (De Garine, 2010), Ф. Деклерк «Екологічні підходи до харчування людини» (Declerck, Fanzo, Palm, Remans, 2011), Л. Калмикова «Культура харчування населення Північної Італії: традиції та новації» (2015), М. Монтанарі «Їжа як культура» (Montanari, 2013) розглядають харчування як феномен культури, що транслює народні звичаї та традиції; частину національної ідентичності, що сприяє ототожненню людини з певним етносом; процес, засоби і передумови комунікації та ін. Здебільшого ці публікації спрямовані на осмислення культурного «коду» та визначення тенденцій розвитку екокультури харчування на сучасному етапі.

Проте досліджень специфіки національної української кухні в контексті концепцій екологічної культури, на жаль, замало, аби висвітлити означене питання.

\section{Мета статті}

Мета статті - виявити специфіку вітчизняних екокультурних традицій харчування в сучасних ресторанах національної української кухні.

\section{Виклад матеріалу дослідження}

На сучасному етапі екологічна стійкість стала невід’ємною частиною ділової практики всіх галузей людської діяльності. Забруднення навколишнього середовища та повітря, викликані зростанням систем виробництва, призводять до появи структурних проблем та зменшують здатність суспільства ефективно реагувати на потреби населення. На думку дослідників, хвороби, фізичні розлади, надмірна вага та психологічні проблеми, викликані незбалансованим харчуванням жителів великих міст відчутно знижують якість життя людини в XXI ст. (Gökdeniz, Erdem, Çeken, 2014, p. 11).

Світові тенденції останніх років засвідчили масштабну популяризацію зелених практик у галузі ресторанної діяльності, збільшення кількості закладів, що працюють згідно визнаних світовою спільнотою норм екологічної культури. Зауважимо, що будь-який ресторан, може отримати відповідну сертифікацію, якщо дотримується у власній практиці таких 
екологічних категорій, як: ефективне використання води, енергії, екологічно чистих продуктів харчування, екологічно чистих меблів та будівельних матеріалів, безпечних засобів для миття посуду і прибирання приміщень, зменшення та переробки відходів та ін.

В Україні ресторанна індустрія інтегрує практики екологічної культури набагато повільніше, в порівнянні 3 іншими сегментами індустрії гостинності, що пояснюється багатьма об’єктивними та суб’єктивними факторами, передусім тривалою відсутністю чітко сформованих вимог до сертифікації екозакладів ресторанного господарства. Проте для більшості ресторанів української кухні дотримання екологічних критеріїв у процесі приготування страв є нормою, оскільки формування меню на основі безпечних органічних продуктів - складова національного спадку культури харчування.

Традиційну кухню, а також характерні кожному народу звичаї харчування дослідники позиціонують не лише як результат симбіозу історії, біології та культури, а й як своєрідне відображення екосистеми (доступність харчових ресурсів, рівень інтенсивності обміну речовин у мешканців конкретного регіону, виникнення національних традицій харчування), в якій вони формувалися (Рамазанова, 2017, с. 110).

Харчування, як сукупність процесів надходження в організм, перетравлення та засвоєння поживних речовин, тобто складова частина обміну речовин, - це спосіб оптимізації використання ресурсів (анатомофізіологічна адаптація до специфічної їжі, формування культурногосподарських типів організації суспільства та ін.). Виробництво їжі принципова екологічна відмінність людини від інших біологічних видів та один із головних проявів його соціальних особливостей (Рамазанова, 2017, с. 111). Специфічні прийоми кулінарної обробки, що застосовуються для розширення набору можливих видів їжі, зумовлені екологічними факторами - вони формують норми соціальної поведінки та забезпечують стійку взаємодію людства 3 навколишнім середовищем. Отже, екологію харчування доцільно розглядати як аналіз сформованої екосистеми 3 точки зору обмінів речовин та енергії, що в ній відбуваються.

На думку дослідників, еволюціонування національної кухні відіграє важливу роль не лише в процесі популяризації певних продуктів харчування, а й в процесі адаптування їжі до вимог і потреб людини, що відповідають культурній нормі на сучасному етапі (Montanari, 2013, p. 12).

За результатами опитування відвідувачів вітчизняних закладів ресторанного господарства, більшість 3 них, а особливо молодь, зацікавлена в посиленні оздоровчих якостей страв, запропонованих у меню та впевнена, що найкориснішою є традиційна кухня (Симахина, Халапсина, Науменко, 2009, с. 76).

Осмислення особливостей національних екокультурних традицій харчування, відповідно до позиціонування його одним із найважливіших розділів екологічної культури, неможливе без ретельного вивчення традиційного складу продуктів харчування, способів приготування страв та ін. Не менш важливим $є$ й встановлення взаємозв'язку зі звичаями, обрядами, віруваннями українського народу та новаторськими принципами харчування і методами приготування їжі, інтегрованими 
в простір національної кухні в процесі міжкультурного взаємообміну, відповідно до провідних сучасних світових екокультурних тенденцій.

Традиційне харчування українців залежало від продуктів, отриманих у процесі сільськогосподарської діяльності, зважаючи на регіональні особливості (землеробство, вівчарство та скотарство, полювання та риболовля, садівництво, збиральництво).

Зазвичай, раціон харчування складався з різноманітних борщів, супів, каші (куліш з пшона, заправлений овочевою піджаркою на салі), паляниці, пампушок, калачів, пирогів, свіжих, солоних, квашених та запечених овочів (буряк, цибуля, часник, картопля, томати, солодкий перець, кукурудза та ін.), свіжого м’яса (насамперед, свинина, менше гов’ядина, курятина, гусятина) та сала в нарізноманітніших термічних обробках (варене, жарене, запечене, копчене, в’ялене), риби (карасі, щуки, лини та лящі), молочних продуктів (ряжанка, кисломолочні сири, кисле молоко, бринза, маслянка, гуслянка), яєць, фруктів, лісових ягід, зелені (шпинат, щавель, кропива, черемша та ін.), узварів, компотів, квасу, трав'яних напоїв та ін.

Харчова поживність страв української кухні відповідає сезонним кліматичним умовам - пізньої осені, взимку та ранньої весни традиційні страви здавна характеризувалися підвищеною енергетичною цінністю (зернові, бобові, м’ясні страви), а задля забезпечення необхідного для організму комплексу вітамінів та мінералів, а також клітчатки, особлива увага приділялася розширенню повсякденного меню різноманітними соліннями, квашеними овочами, горіхами, сушеними грибами, фруктами та ягодами. Натомість пізньої весни, влітку та ранної осені, коли через високу температуру повітря зменшується активність діяльності травних залоз, українці надавали перевагу їжі, що легко засвоюється (молочні продукти та рослинна їжа).

Аналізуючи раціон повсякденного харчування українців в історичній ретроспективі, можемо зазначити, що він забезпечував повноцінне надходження до організму необхідних вітамінів та мінералів.

Екологічно чисті продукти рослинного та тваринного походження м'ясо, овочі, фрукти, ягоди, зелень, молоко, сир, хліб та ін., - основа національної кухні. Саме вони пітримували здоров'я та упереджували хвороби багатьох поколінь. Наприклад, часник, цибуля та хрон, які $€$ обов’язковими складовими інгредієнтами українських традиційних страв, наділені властивостями природних антибіотиків, здійснюють позитивний вплив на імунну систему, а також сприяють уповільненню агрегації тромбоцитів. Гриби, горіхи, зелень та лісові ягоди, які переважають в українській кухні влітку-восени, мають протизапальний та антибактеріальний ефект, покращують процеси травлення та попереджують відкладення солей в суглобах. Солоні та квашені продукти зимово-весняного меню (капуста, огірки, яблука, слива, перець та ін.) сприяють корегуванню необхідного складу мікрофлори кишечника, відповідно нормалізують функціонування системи травлення та організма в цілому. У багатьох стравах молочні продукти поєднуються з рослинною їжею (наприклад, зелений борщ, млинці 3 сиром та ягодами, гриби в сметанному соусі та ін.), а відтак необхідні людині поживні речовини, поєднано з клітчаткою, вітамінами та мінералами. 
Екокультурними традиціями національної української кухні, що визнані світовою спільною як важлива складова екологічного харчування в закладах ресторанного господарства $є$ :

- використання продуктів, вирощених у власних господарствах, або зібраних чи впольованих на екологічно чистих територіях;

- збалансована поживна цінність харчових продуктів;

- різноманітне святкове та повсякденне меню (розмаїття продуктів харчування та підвищення смакових якостей страв, які сприяють кращому засвоєнню їжі організмом);

- сезонність меню.

Поставка високоякісних продуктів у закладах ресторанного господарства позиціонується необхідною умовою для забезпечення стабільного високого рівня обслуговування клієнтів. Популярною тенденцією сучасних вітчизняних екоресторанів $є$ вирощення екологічно чистих та безпечних для здоров’я продуктів харчування на місці - безпосередньо на території закладів ресторанного господарства або на спеціальних власних фермах, а також співпраця з фермерськими господарствами, які дотримуються світових стандартів екологічної культури. Місцеві продукти, включення яких до меню сприяє збільшенню кількості відвідувачів та розширенню контингенту, наразі визначаються дослідниками як такі, що вирощуються на відстані менше 200-т км від закладу в якому споживаються (Johnson, 2010).

Особливу увагу сфоксуємо саме на сезонності меню української кухні. Сучасні дослідники стверджують, що його посилення $є$ одним зі способів повідомити відвідувачів не лише про високу якість продуктів харчування, а й про дотримання та популяризацію принципів екологічної безпеки керівництвом закладу (Sundkvist, Milestad, Jansson, 2005, p. 226). Зазначимо, що окрім позитивного впливу на здоров'я відвідувачів (організм людини налаштовується на ритми простору місцевості проживання, відповідно найкраще засвоює частоти саме місцевих продуктів), подібна екологічна практика сприяє зменшенню негативного впливу людини на навколишнє середовище - викидів парникових газів у процесі транспортування продуктів.

Окрім того, зауважимо, що інтер’єрні традиції українських національних ресторанів також цілком відповідають стандартам екологічної культури XXI ст. Характерною ознакою більшості сучасних закладів ресторанного господарства, що спеціалізуються на стравах української кухні є дерев’яні меблі, хмизові тини, холщові скатертини, використання керамічного посуду, декорування предметами сільського побуту, сушеними травами та ін.

На сучасному етапі екоресторани національної української кухні набувають особливої популярності завдяки активній діяльності послідовників руху «Слоу фуд». 
Експортування продуктів харчування та інтегрування традицій інших культур, наприкінці XX ст. призвели до негативної тенденції зменшення національної самобутності їжі, оскільки саме місцеві продукти є важливим фактором збереження біорізноманіття планети, культурного спадку та відчуття приналежності до нації. Своєрідним проявом індивідуалізму в національних гастрономічних культурах став рух «Слоу фуд» (зародився в Італії у 1986 р.; нині популярний у більш ніж 160-ти країнах), завданням послідовників якого $є$ протиставлення національного глобальному, місцевих ферм транснаціональним корпораціям, стандартизації та уніфікації (макдональдизації) - захист культурних традицій, пов'язаних 3 місцевою гастрономічною культурою та особливостями національної кухні певного регіону (Борисова, 2017, с. 73-74).

Наразі багато українських рестораторів, шеф-поварів, виробників (фермерів) та споживачів є членами всесвітньої організації «Slow Food Internstional». Вони активно сприяють пошуку та захисту традиційних продуктів та рецептів, порід та сортів, важливих в історичному та національному сенсі (проект «Ковчег смаку»); формують «Альянс Поварів Слоу Фуд», головною метою якого є об'єднання діяльності 3 метою надання споживачу через ресторанну кухню свіжих, екологічно безпечних продуктів безпосередньо з сільських господарств.

\section{Висновки}

Одним із трендів вітчизняних закладів ресторанного господарства на сучасному етапі $є$ підвищення престижності традиційних продуктів та страв української кухні, звернення до сформованих протягом століть національних екокультурних норм харчування. Це пояснюється світовою тенденцією - активізацією екологічної свідомості людини, осмисленням особистої відповідальності за збереження населення Землі, яке відбувається завдяки зміні світосприйняття, перегляду культурних цінностей, 3 метою формування та розвитку екологічної культури XXI ст. як необхідної передумови для еволюціонування цивілізації. Еволюціонування національної української кухні відіграє важливу роль не лише в процесі популяризації певних продуктів харчування, а й в процесі адаптування їжі до вимог і потреб українців, що відповідають культурній нормі на сучасному етапі. Перспективи подальших досліджень зумовлені актуальністю проблематики екологічної культури в галузі ресторанної діяльності. Зокрема, належного висвітлення потребує специфіка реалізації екологічної практики у сучасних вітчизняних закладах ресторанного господарства.

\section{Список використаних джерел}

1. Борисова Д. С. «Слоу фуд»: сохранение нематериального культурного наследия Италии. Вестник Санкт-Петербургского государственного университета культуры и искусств. 2017. № 4 (33). С. 70-75. 
2. Калмикова Л. В. Культура питания населения Северной Италии: традиции и новации : дис. канд. исторических наук / Москов. гос. ун-т им. М. В. Ломоносова. Москва, 2015. 192 с.

3. Рамазанова 3.Б. Питание сельского населения Нагорного Дагестана как важнейший механізм этноэкологической адаптации. Вестник института этнологии и антропологии. 2017. № 2. С. 107-118.

4. Симахина Г., Халапсина С., Науменко Н. Традиционная украинская кухня в системе оздоровительного питания. Продукты \& ингридиенты : производство, переработка, хранение, реализация. 2009. № 2. С. 76-77.

5. De Garine I. The socio-cultural aspects of nutrition. Ecology of Food and Nutrition. 2010. Vol. 1. Issue 2. P. 143-163. https://doi.org/10.1080/03670244.1972.99 90282.

6. Declerck F., Fanzo J., Palm Ch., Remans R. Ecological Approaches to Human Nutrition. Food and nutrition bulletin. 2011. № 32. P.41-50. DOI: 10.1177/15648265110321S106.

7. Gökdeniz A., Erdem B., Çeken H. Eco-friendly practices in the lodging industry: the case of Ayvalik Cunda Ortunc Hotel, Turkey. International Journal for Responsible Tourism. 2014. № 3(1). P. 7-21.

8. Johnson M. R. Environmental sustainability within the restaurant industry. 2010. URL: https://courses.cit.cornell.edu/crp384/2009reports/JohnsonM_Sustainable\%20 Restaurant\%20Industry.pdf (Accessed: 11 April 2019).

9. Montanari M. Comida como cultura. São Paulo: Editora Senac, 2013. 170 p.

10. Sundkvist A., Milestad R., Jansson A. On the importance of tightening feedback loops for sustainable development of food systems. Food Policy. 2005. № 30. P. 224-239.

\section{References}

Borisova, D.S. (2017). “Slou fud”: sohranenie nematerialnogo kulturnogo naslediya Italii ["Slow Food": preservation of the intangible cultural heritage of Italy]. Vestnik SanktPeterburgskogo gosudarstvennogo universiteta kulturyi i iskusstv, no. 4 (33), pp. 70-75.

De Garine, I. (2010). The socio-cultural aspects of nutrition. Ecology of Food and Nutrition, vol. 1, issue 2, pp. 143-163.

Declerck, F., Fanzo, J., Palm, Ch. and Remans, R. (2011). Ecological Approaches to Human Nutrition. Food and nutrition bulletin, no. 32, pp.41-50. DOI: 10.1177/15648265110321S106.

Gökdeniz, A., Erdem, B., ve Çeken, H. (2014). Eco-friendly practices in the lodging industry: the case of Ayvalik Cunda Ortunc Hotel, Turkey. International Journal for Responsible Tourism, no. 3(1), pp. 7-21.

Johnson, M.R. (2010). Environmental sustainability within the restaurant industry. Available at : $\quad$ https://courses.cit.cornell.edu/crp384/2009reports/JohnsonM_Sustainable\%20 Restaurant\%20Industry.pdf > [Accessed: 11 April 2019].

Kalmikova, L.V. (2015). Kultura pitaniya naseleniya Severnoy Italii: traditsii i innovatsii [Food Culture of the Population of Northern Italy: Traditions and Innovations]. DEd. Lomonosov Moscow State University. 
Montanari, M. (2013). Comida como cultura. São Paulo: Editora Senac.

Ramazanova, Z.B. (2017). Pitanie selskogo naseleniya Nagornogo Dagestana kak vazhneyshiy mehanizm etnoekologicheskoy adaptatsii [Food of the rural population of Nagorno-Dagestan as the most important mechanism of ethno-ecological adaptation]. Vestnik instituta etnologii i antropologii, no. 2, pp. 107-118.

Simahina, G., Halapsina, S. and Naumenko, N. (2009). Traditsionnaya ukrainskaya kuhnya $\mathrm{v}$ sisteme ozdorovitelnogo pitaniya [Traditional Ukrainian cuisine in the system of healthy food]. Produktyi \& ingridientyi : proizvodstvo, pererabotka, hranenie, realizatsiya: nauchno-prakticheskiy zhurnal, no. 2, pp. 76-77.

Sundkvist, A., Milestad, R. and Jansson, A. (2005). On the importance of tightening feedback loops for sustainable development of food systems. Food Policy, no. 30, pp. 224-239.

Стаття надійшла до редакйї: 27.03.2019

\title{
NATIONAL ECO-CULTURAL TRADITIONS AT MODERN RESTAURANTS
}

\author{
Maryna Bratitsel
}

Teaching assistant, ORCID: 0000-0001-9206-3479, frog2014137@gmail.com, Kyiv National University of Culture and Arts, Kyiv, Ukraine

The purpose of the article is to reveal the specifics of Ukrainian ecocultural eating habits at modern restaurants of national Ukrainian cuisine. The research methodology is based on a combination of the fundamental principles of the theory of social ecology, the principles of socio-ecological and cultural approach to the study of ecological culture. Considering the interdisciplinary nature of this issue, in the process of research and analysis of national eco-cultural traditions at modern restaurants, integrated, value, structural-functional and factorial approaches were used; methods of modeling, system analysis and generalization, which contributed to the understanding of the implementing mechanisms of the basic principles of ecological culture in the field of restaurant industry. The scientific novelty. The evolution features of the national eating habits at modern restaurants of Ukrainian cuisine found to coincide with the internationally recognized basic principles of ecological culture of the 21st century. Conclusions. Now one of the trends of Ukrainian restaurants is to increase the prestige of traditional products and dishes of Ukrainian cuisine, to apply to the national eco-cultural norms that have been established for centuries. This is due to the global trend the activation of human ecological consciousness, comprehension of personal responsibility for the preservation of the population of the Earth, which occurs due to a change in world view, viewing cultural values, with the goal to form and develo an ecological culture of the 21 st century as a necessary prerequisite for the evolution of civilization. The development of national Ukrainian cuisine plays an important role not only in the process of promoting 
certain foods, but also in the process of their adaptation to the requirements and needs that meet the cultural standard of Ukrainians at the present days.

Keywords: Ukrainian cuisine; ecological culture; eco-cultural traditions; nutrition; restaurants.

\title{
НАЦИОНАЛЬНЫЕ ЭКОКУЛЬТУРНЫЕ ТРАДИЦИИ В СОВРЕМЕННЫХ РЕСТОРАННЫХ ЗАВЕДЕНИЯХ
}

\author{
Братицел Марина Леонидовна
}

\section{Ассистент,}

ORCID: 0000-0001-9206-3479, frog2014137@gmail.com,

Киевский национальный университет культуры и искусств, Киев, Украина

Цель статьи - выявить специфику отечественных екокультурних традиций питания в современных ресторанах национальной украинской кухни. Методология исследования основана на совокупности фундаментальных принципов теории социальной экологии, принципов социально-экологического и культурного подхода к изучению экологической культуры. Учитывая междисциплинарный характер данного вопроса, в процессе исследования и анализа национальных экокультурных традиций в современных ресторанных заведениях применялись интегрированные, ценностные, структурно-функциональные и факторные подходы; методы моделирования, системного анализа и обобщения, которые способствовали пониманию механизмов реализации основных принципов экологической культуры в области ресторанного хозяйства. Научная новизна. Определены особенности национальных экокультурних традиций питания в современных ресторанах украинской кухни и обнаружено, что они совпадают с всемирно признанными базовыми принципами экологической культуры XXI века. Выводы. Одним из трендов отечественных заведений ресторанного хозяйства на современном этапе является повышение престижности традиционных продуктов и блюд украинской кухни, обращение к сложившимся на протяжении веков национальных экокультурных норм питания. Это объясняется мировой тенденцией - активизацией экологического сознания человека, осмыслением личной ответственности за сохранение населения Земли, которое происходит благодаря изменению мировосприятия, просмотра культурных ценностей, с целью формирования и развития экологической культуры XXI века как необходимой предпосылки для эволюционирования цивилизации. Развитие национальной украинской кухни играет важную роль не только в процессе популяризации определенных продуктов питания, но и в процессе их адаптации к требованиям и потребностям, которые соответствуют культурной норме украинцев на современном этапе.

Ключевые слова: украинская кухня; экологическая культура; экокультурные традиции; питание; заведения ресторанного хозяйства. 